\title{
Strategi Restructuring Cognitive Dalam Konseling Kelompok CBT Untuk Meningkatkan Kepercayaan Diri Siswa Kelas VIII G di SMP PGRI 1 Buduran Sidoarjo
}

\author{
Oom Linda Rukmana ${ }^{1}$, Kusbandiami ${ }^{2}$, Maghfirotul Lathifah ${ }^{3}$ \\ Bimbingan dan Konseling, Fakultas Keguruan dan Ilmu Pendidikan, Universitas \\ PGRI Adi Buana Surabaya ${ }^{1,2, \& 3}$ \\ Email: oomlindaruk@gmail.com ${ }^{1}$, kusbandiami@unipasby.ac.id ${ }^{2}$, \\ maghfirotul@unipasby.ac.id ${ }^{3}$
}

\begin{abstract}
:
This study aims to determine the effect of the use of cognitive restructuring strategies in group counseling on class VIII G students' confidence in SMP PGRI 1 Buduran Sidoarjo. The research design used was a Pre-Experimental study with a One Group Pretest-Postest Design. The population of class VIII G students at SMP PGRI 1 Buduran Sidoarjo was 30 students, then 4 students were taken as research samples using purposive sampling techniques. The selection of this sample was chosen based on the results of students' low self-confidence scores through filling in the scale of student confidence measurement. The results of this study was found that there was no significance changed in the use of cognitive restructuring in counseling group on the confidence of students of class VIII G in SMP PGRI 1 Buduran Sidoarjo.
\end{abstract}

Keyword: self confidence,cbt, restructuring cognitive

Received February 20, 2020; Revised March 25, 2020; Accepted April 1, 2020

How to Cite: Rukmana O. M., Kusbandiami, \& Lathifah M. (2020). Pengaruh Strategi Restructuring Cognitive dalam Konseling Kelompok CBT Terhadap Kepercayaan Diri Siswa SMP. JKI (Jurnal Konseling Indonesia), 5(2), 62-67.

\section{PENDAHULUAN}

Kepercayaan diri merupakan suatu sikap yang harus dimiliki oleh setiap individu. Individu yang memiliki rasa percaya diri, akan sangat mudah berinteraksi dengan lingkungannya baik dalam lingkup belajar, sosialisasi, karir, ataupun hal lainnya. Begitu sebaliknya jika individu kurang memiliki rasa percaya diri maka individu akan lebih sulit untuk beradaptasi dengan lingkungannya bahkan dalam lingkungan sekolah atau dalam proses belajar dapat mengakibatkan penurunan prestasi yang dimiliki karena kurangnya rasa percaya diri tersebut. Setiap individu memiliki keunikan yang artinya individu mempunyai karakteristik yang berbeda antara individu satu dengan yang lain. Salah satu sikap yang dimunculkan oleh individu dalam keseharian yakni pendiam, menunjukkan sikap tidak percaya diri, minder, menjauh dari lingkungan sosial, dsb. Kepercayaan diri adalah suatu dasar utama dalam individu untuk mengaktualisasikan potensi yang ada didalam dirinya (Komara, 2011). Percaya diri merupakan sikap positif individu yang mampu untuk mengembangkan penilaian positif terhadap lingkungan atau situasi yang dihadapinya (Agustine, 2018). Menurut Nadiah (2019) kepercayaan diri merupakan suatu pengalaman dalam diri yang memiliki aspek kepribadian diantaranya keyakinan atas kemampuan dalam diri sehingga tidak terpengaruh 
oleh orang lain dan dapat bertindak sesuai kehendak, gembira, optimis, toleransi, dan bertanggungjawab. Dapat disimpulkan dari beberapa tokoh dan peneliti mengenai kepercyaan diri ialah suatu sikap positif yang dimiliki individu berupa keyakinan, kemampuan diri, kemandirian, serta kekuatan untuk mencapai tujuan dalam dirinya.

Berdasarkan hasil observasi yang dilakukan oleh peneliti selama 2 bulan, fenomena yang sering muncul dikalangan siswa dimasa awal remaja hingga remaja yaitu salah satunya di SMP PGRI 1 Buduran Sidoarjo. Terdapat siswa yang menampakkan perilaku yang merugikan dirinya secara tidak sadar, salah satunya ketika mengikuti seluruh mata pelajaran banyak siswa yang menampakan sikap pendiam, jika guru menjelaskan dan memberikan peluang kepada siswanya untuk bertanya ataupun menjawab siswa pun hanya terdiam. Hal ini terdapat alasan mengenai hal tersebut atau menjadi alasan bagi siswa menampakan sikap tersebut. Diantaranya jika ditanya dengan guru mata pelajaran siswa terdiam yakni siswa merasa takut jika jawaban yang dia lontarkan itu salah dan takut jika ditertawakan apabila jawabannya salah maka dari itu siswa memilih diam, sama halnya ketika presentasi didepan kelas baik secara kelompok atau individu siswa merasa cemas karena takut jika apa yang dipresentasikan tidak dipahami oleh teman-temannya dan takut jika ditertawakan didepan kelas, meskipun siswa tersebut sudah belajar dan mempersiapkan dengan matang sebelum presentasi dan merasa siap tetapi ketika didepan kelas pikiran dan perasaan tersebut muncul sehingga siswa merasa tidak percaya diri. Dalam lingkungan pertemanan (sosial) terdapat fenomena dimana siswa pendiam jika diajak teman-temannya berbicara atau bermain bersama, saat diajak berkelompok siswa tersebut cenderung diam dan selalu mengikuti apa yang menjadi bahasan dalam kelompok, siswa tidak pernah berpendapat dalam sistem berkelompok tersebut. Hal ini bisa dikarenakan faktor tidak percaya diri dalam siswa tersebut.

Individu yang memiliki rasa percaya diri, akan sangat mudah berinteraksi dengan lingkungannya baik dalam lingkup belajar, sosialisasi, karir, ataupun hal lainnya. Begitu sebaliknya jika individu kurang memiliki rasa percaya diri maka individu akan lebih sulit untuk beradaptasi dengan lingkungannya bahkan dalam lingkungan sekolah atau dalam proses belajar dapat mengakibatkan penurunan prestasi yang dimiliki karena kurangnya rasa percaya diri tersebut. Salah satunya dampak yang terlihat ketika siswa merasa takut ingin bertanya kepada gurunya hal yang dilakukan ialah diam dan mendengarkan, padahal siswa tersebut tidak faham akan apa yang telah dijelaskan, hal ini berdampak pada nilai kuis yang telah dilakukan, siswa tersebut mendapatkan nilai buruk karena tidak faham akan materi dan memiliki kepercayaan diri yang rendah sehingga memiliki dampak buruk bagi akademiknya. Selain itu didalam sosial atau interaksi dengan teman sebaya, siswa yang memiliki kurang kepercayaan diri akan memilih diam ketika dikelas yang akan berdampak pada pertemanannya. Siswa tersebut tidak memiliki teman dikelas karena memiliki pemikiran negative "saya tidak bisa dan tidak ada yang ingin berteman dengan saya".

Adapun faktor yang menyebabkan timbulnya kepercayaan diri yang rendah diantaranya faktor dari dalam diri individu berupa dominan pemikiran yang negative, tidak meyakini bahwa dirinya mampu dalam bidang atau hal yang ingin dilakukan, kurangnya memiliki rasa keoptimisan dalam diri, adanya rasa minder yang cukup tinggi, bahkan tidak memiliki tujuan yang ingin dicapai. Selain itu terdapat faktor lingkungan yang dapat mempengaruhi individu tersebut, diantaranya faktor lingkungan keluarga, sekolah, dan lingkungan sosial (teman sebaya). Menurut Safta (2015) hal yang diperhatikan dalam kepercayaan diri diantaranya yakin dengan kemampuan diri, optimis, objektif, bertanggung jawab, dan realistis individu akan merasa optimal dalam kepercayaan diri yang dimilikinya.

Dari pemaparan diatas untuk menanggulanginya dapat dilakukan strategi restructuring cognitive dalam konseling kelompok dengan pendekatan CBT (Cognitive Behaviour therapy). Peneliti menggunakan strategi diatas karena akar dari fenomena banyaknya siswa yang memiliki kurangnya rasa kepercayaan diri yang rendah yakni dari pemikiran negative yang digeluti oleh dirinya. Individu memiliki problema pada pemikirannya sehingga mengakibatkan kesimpulan tersendiri dalam hal negative yang merugikan dirinya sendiri apabila tidak ditangani dan disadari. Dari pemikiran negatif yang dimiliki individu jika dibiarkan akan menciptkan perilaku yang maladaptif atau merugikan bagi dirinya sendiri, maka dari itu berhubungan dengan tujuan dari strategi restructuring cognitive yakni mengubah atau mengkonstruk pemikiran yang irasional (negatif) yang menganggap dan meyakini dirinya tidak memiliki kemampuan menjadi pemikiran yang rasional (positif) bahwa setiap individu memiliki potensi yang berbeda antar individu, sehingga individu lebih percaya diri.

Strategi restructuring kognitif dirancang khusus untuk individu dengan gangguan psikotik dan suasana hati dengan berfokus pada modifikasi disfungsional keyakinan dan perilaku (Saputra, 2017). Restructuring kognitif dapat dikatakan sebagai menkonstruk atau mestruktur ulang kognitif atau pemikiran individu dari pemikiran negative dikonstruk menjadi pemikiran yang lebih positif. Sedangkan CBT merupakan suatu pendektaan konseling yang menekankan pada terapi kognitif. Tujuan dari CBT yaitu (1) mengenali pemikiran yang negative dari dalam diri, (2) mengurangi intensitas dan frekuensi gejala yang bermasalah, (3)mengembangkan respon adaptif, (4) meningkatkan keterampilan dalam mengubah kehal positif, (5) mencegah kekambuhan atau mecegah kembali atas problema yang telah diselesaikan. Focus utama dalam pendekatan ini yaitu pada awalnya pada mengidentifikasi dan menantang pemikiran irasional yang mengarah ada mengalah diri sendiri baik respon secara emosional dan perilaku (Drab, 2010). 
Peneliti menggunakan strategi restructuring cognitive dengan pendekatan konseling kelompok CBT yaitu pendekatan CBT merupakan suatu pendekatan dimana tujuan atau goals sama dengan strategi restructuring cognitive yaitu berfokus pada pengubahan atau mengkonstruk pemikiran irasional (negative) menjadi pemirikan yang rasional (positif) dapat diterima oleh dirinya dan lingkungannya. Dibuktikan dengan adanya penelitian oleh (Saragih, Wibowo, \& Awalya, 2018) dalam hasil penelitiannya sebanyak 7 sampel yang digunakan peneliti menunjukkan bahwa konseling kelompok terapi perilaku kognitif efektif untuk meningkatkan citra tubuh siswa. Selain itu penelitian yang dilakukan oleh (Thimm \& Antonsen, 2014) mengatakan bahwa penanganan secara kelompok dengan strategi CBT memiliki hasil yang baik dan signifikan pada tingkat individu dalam menangani depresi. Dapat disimpulkan oleh peniliti bahwa pendekatan CBT dapat digunakan sebagai salah satu penanganan untuk meningkatkan kepercayaan diri siswa secara kelompok yang dikombinasikan dengan strategi Restrukturing Cognitive.

\section{METODE PENELITIAN}

Penelitian ini menggunakan penelitian pra-eksperimental jenis one group pretest-posttets design. Pada desain penelitian ini menggunakan 2 cara yakni dengan memberikan pretest kepada sampel penelitian sebelum diberi perlakuan. Setelah itu diberi posttest kepada sampel penelitian yang telah diberi perlakuan atau treatment dan mengukur apakah sampel mengalami perubahan sebelum dan setelah diberi perlakuan. Menurut Creswell \& Creswell (2017) desain penelitian ini berfungsi untuk membandingkan secara akurat (pretest dan posttest) sebelum dan sesudah diberi perlakuan oleh peneliti terhadap sampel yang teliti.

Perlakuan yang diberikan berupa layanan konseling kelompok selama 6 kali pertemuan dan setiap tatap muka dilakukan selama 40 menit. Populasi dalam penelitian ini menggunakan kelas VIII G sebanyak 30 siswa. Kemudian peneliti mengambil 4 sampel dengan teknik purposive sampling yaitu dalam pengambilan sampel, peneliti memiliki pertimbangan sesuai dengan ketentuan yang telah ditentukan oleh peneliti(Sugiyono, 2017, p. 124), diantaranya peneliti memiliki kriteria atas pengukuran mengenai kepercayaan diri (adanya indicator). Terdapat 2 variabel dalam penelitian ini diantaranya, variable terikat yakni kepercayaan diri siswa, dan variable bebas yakni konseling kelompok CBT dengan strategi restructuring cognitive.

Teknik pengumpulan data dalam penelitian ini menggunakan kuisoner dengan cara penskoran skala, yakni skala likert. Dimana skala likert ialah skala yang digunakan untuk mengukur suatu sikap, pendapat, dan persepsi seseorang atau sekelompok orang mengenai suatu gejala atau fenomena pendidikan (Mudhar \& Muwakhidah, 2017, p. 70). Analisis data yang digunakan yaitu statistika non parametric dengan teknik uji Wilcoxon pada SPSS For Windows versi 24.0.

\section{HASIL}

Berdasarkan hasil penelitian terhadap 4 sampel yang diberikan layanan konseling kelompok CBT dengan strategi restructuring kognitif menyatakan bahwa terdapat perubahan setelah diberikan pelayanan tetapi terdapat satu konseli yang memang mengalami penurunan. Berikut ialah tabel 1 hasil penelitian:

Table 1. hasil pre-test dan post-test

\begin{tabular}{|c|c|c|c|c|c|}
\hline Kepercayaan Diri Siswa Kelas VII G di SMP PGRI 1 Buduran Sidoarjo \\
\hline No. & $\begin{array}{c}\text { Sampel } \\
\text { Penelitian }\end{array}$ & Pre-Tes & Kategori & Post-Tes & Kategori \\
\hline 1 & MW & 47 & Rendah & 58 & Sedang \\
\hline 2 & WD & 46 & Rendah & 44 & Rendah \\
\hline 3 & RI & 47 & Rendah & 60 & Sedang \\
\hline 4 & SA & 47 & Rendah & 58 & Sedang \\
\hline
\end{tabular}

Dari hasil diatas terdapat peningkatan skor dari pre-test ke post test, dan terdapat penurunan skor pre-test dan post test. Adapun terjadinya peningkatan dan penurunan yang dialami oleh responden tersebut disebabkan oleh berbagai factor yang melatar belakangi individu. Salah satunya factor sampel yang mengalami penurunan setelah diberikan layanan ialah permasalahan yang dialami WD merasa takut dan menganggap dirinya memiliki wajah yang tidak tampan (fisik), selain itu WD juga pernah mengalami hal yang tidak menyenangkan di kelas yaitu diejek oleh temannya karena suaranya yang sangat pelan. WD selalu diam dikelas dan suaranya sangat kecil ketika berbicara. WD tinggal bersama kakaknya dan berpisah dengan kedua orang tuanya. Orang tuanya tinggal disatu daerah yang sama tetapi berbeda rumah. Kedua orang tua WD mengunjungi WD dan kakaknya hanya disaat pagi 
hari setelah itu kembali bekerja dan kembali kerumah masing-masing. WD sangat senang dengan permainan games online. WD lebih memilih bermain games dan diam dari pada berinteraksi dengan lingkungan sekitarnya. Setelah mendapatkan treatment WD mengalami kemunduran, hal ini diduga karena kondisi keluarga yang sudah lama jarang berkomunikasi dan dorongan dari dalam individu yang masih merasakan kenyamanan bahwa diam ialah pilihan yang terbaik. Adapun hasil grafik 1 penelitian yang telah dilakukan, sebagai berikut:

Grafik 1. hasil pre-test dan post-test

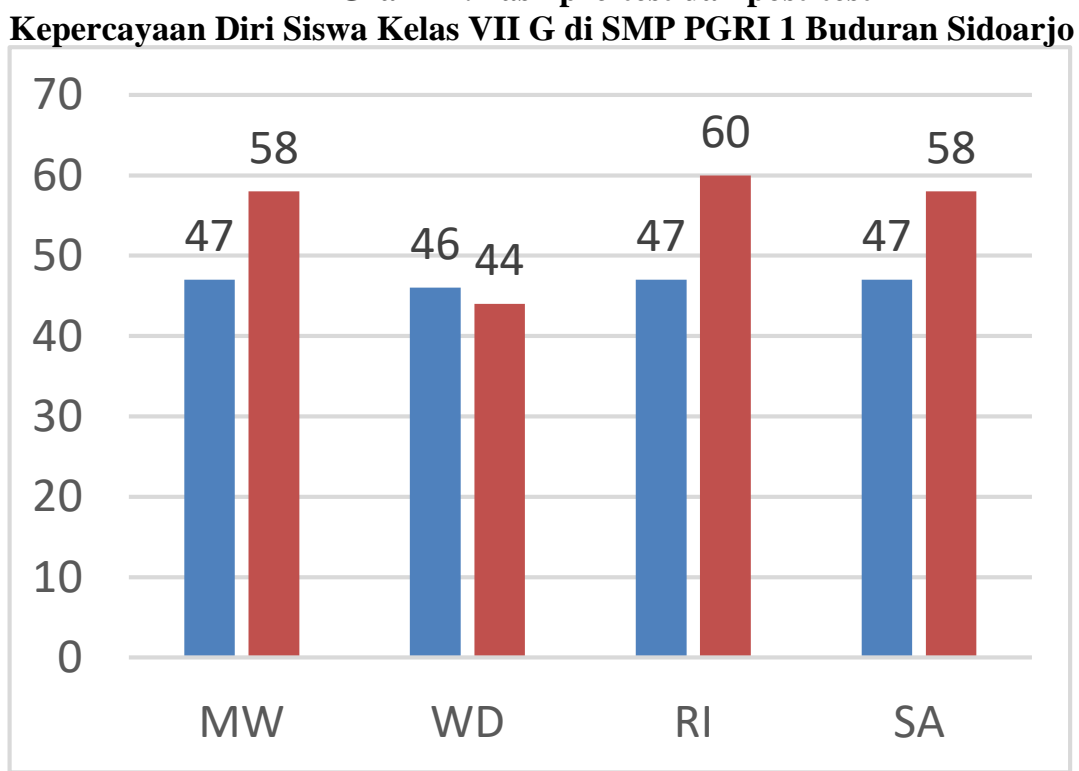

Dari grafik diatas rata-rata responden mengalami peningkatan skor kisaran 11-13 point. Responden MW mengalami peningkatan 11 point. Responden WD mengalami penurunan 2 point. Responden RI mengalami peningkatan sebesar 13 point dan responden SA mengalami kenaikan 11 point.

Berdasarkan analisis non parametrik dengan uji wilxocon menggunakan SPSS versi 24. Adapun hasil uji Wilcoxon yakni bernilai 0,141 dimana dalam taraf signifikansi hipotesis penelitian dapat diterima jika sig $<0,05$ maka dapat dikatakan penelitian ini memiliki pengaruh yang signifikan dalam penggunaan strategi terhadap masalah yang ditinjau, begitu sebaliknya jika nilai sig > 0,05 maka dikatakan penelitian ini tidak memiliki pengaruh. Dari hasil nilai uji Wilcoxon yang bernilai $0,141>0,05$ (sig), yang artinya hasil uji Wilcoxon lebih besar dari pada nilai taraf signifkan. Maka dapat dikatakan bahwa penelitian ini tidak memiliki pengaruh secara signifikan dalam penggunaan strategi restructuring cognitive dalam konseling kelompok CBT terhadap kepercayaan diri siswa.

\section{PEMBAHASAN}

Kepercayaan diri merupakan suatu sikap positif yang dimiliki individu berupa keyakinan, kemampuan diri, kemandirian, serta kekuatan untuk mencapai tujuan dalam dirinya (Oney \& Oksuzoglu-Guven, 2015). Hal ini mengartikan bahwa individu yang memiliki kepercayaan diri adalah individu yang memiliki keyakinan dalam dirinya bahwa dirinya memiliki potensi, menerima potensi yang dimiliki dan menyadari bahwa setiap individu memiliki kelebihan dan kekurangan masing-masing salah satunya potensi dalam diri individu yang berbeda. Memiliki kemandirian artinya individu mandiri atas prestasi yang dimiliki sesuai dengan kemampuannya tidak bergantung pada orang lain. Memiliki kekuatan untuk mencapai tujuan dalam dirinya yang memiliki arti individu memiliki keoptimisan dan pantang menyerah dalam mencapai tujuan. Salah satu fenomena ditempat sekolah masih terdapat siswa yang tidak memiliki kepercayaan diri atau memiliki kepercayaan diri yang rendah, hal ini disebabkan karena individu tidak memiliki keyakinan dalam dirinya dan faktor lain karena adanya pengalaman tidak menyenangkan sehingga individu merasa dan memiliki pemikiran bahwa dirinya tidak mampu dan tidak memiliki potensi. Hal ini berhubungan dengan cara berfikir individu yang mengakibatkan timbulnya sikap tidak percaya diri.

Pemikiran negatif (irasional) akan mempengaruhi sikap yang ditampakan oleh individu, begitu sebaliknya pemikiran positif dapat mempengaruhi sikap individu. berhubungan dengan hal ini maka perlu dilakukan layanan dalam membantu siswa dengan cara memberikan layanan responsif yakni dengan melakukan konseling secara 
kelompok. Salah satu teori yang dapat membantu dalam hal mengubah atau mengkonstruk pemikiran negatif individu (konseli) menjadi pikiran positif yakni dengan menggunakan teori restructuring cognitive dengan CBT (Cognitive Behavior Therapy). Adapun proses penelitian ini mengkombinasi antara tahapan CBT dengan strategi restructuring cognitive Adapun tahapan CBT diantaranya: (1) konseli dan konselor mendiskusikan dan mefokuskan masalah yang akan ditangani dan membuat planning selama seminggu; (2) konseli dan konselor merencanakan strategi untuk mengangani maslaah yang sudah ditentukan; (3) meninjau tugas konseli dari sesi sebelumnya dan membahas kemajuan konseli; (4) setelah membahas tugas sebelumnya, konselor memberikan tugas baru untuk pertemuan minggu yang akan datang untuk kemajuan yang lebih baik (Fernandez, Salem, Swift \& Ramtahal, 2015) .

Sedangkan strategi restructuring kognitif terdapat 6 tahapan diantaranya: (1) mengungkapkan dan mengidentifikasi masalah yang dihadapi; (2) mencatat perasaan negative yang dialami. Biasanya menggunakan kata seperti sedih, jengkel, marah, cemas, malu,terhina, dsb; (3) mencatat atau merekam dalam diri atas pemikiran negative yang dialami. Perhatikan apa yang dikatakan pada diri sendiri tentang masalah yang ada; (4) menganalisis pemikiran menggunanakan salah satu metode baik menggunakan daftar list ataupun kolom. Analisis ini harus menunjukkan bagaimana pemikiran irasional dan mulai merubah ke pemikiran rasional sehingga nilai kepercayaan diri mulai tumbuh; (5) membangun pemikiran realistis dan seimbang (rasional); (6) mengevaluasi proses restrukturasi yang telah dilakukan. Jika dalam tahapan restructuring kognitif ini kurang berhasil maka dapat kembali dilakukan ulang mulai tahap ke 4 (Wenzel, 2017).

Adanya tahapan masing-masing dalam pendekatan CBT dengan strategi restructuring kognitif maka terdapat kombinasi dalam pengimplementasian yang dilakukan oleh peneliti. Sehingga peneliti mengimplementasikan tahapan restructuring kognitif dalam tahapan CBT yang ke-2 setelah itu dilanjut dengan 4 tahapan CBT yang sudah tertera. Peneliti melakukan 6 kali pertemuan yang dilakukan tiap minggunya. Adapun capaian yang sudah ditentukan yaitu (1) konseli mampu mengenali setiap anggota kelompok dan memahami satu sama lain dengan banyaknya perbedaan disetiap anggota; (2) konseli mampu mengungkapkan masalah yang dihadapi yang berhubungan dengan rasa kepercayaan diri; (3) mampu mengidentifikasi masalah dan pemikiran irasional yang dirasakan dan dialami; (4) konseli mampu dan mengimplementasikan pemikiran yang telah dikonstruk dari pemikiran negative menjadi pemikiran yang lebih positif; (5) konseli dapat mengimplementasikan dengan perlahan tingkatan kepercayaan diri; (6) konseli mampu mengungkapkan dan mengevaluasi diri setelah mengimplementasikan tujuan dari konseling ini.

Penelitian yang terkait dengan kepercayaan diri yakni dari (Nurkia \& Sulkifly, 2020) mengatakan bahwa dalam penelitiannya yang berjudul Penerapan Teknik Konseling Restrukturasi Kognitif untuk Meningkatkan Kepercayaan Diri Siswa di MAN Baraka. Menyatakan restrukturasi kognitif dapat meningkatkan kepercayaan diri siswa kelas XI IPA di MAN Baraka Kabupaten Enrekang, dengan melalui tujuh tahapan diantaranya melakukan asesmen dan diagnosa, mengidentifikasi pikiran negatif siswa, memonitor pikiran negatif siswa melalui rekaman pikiran dan tahapan akhirnya yakni intervensi pikiran negatif menjadi pikiran positif dalam diri siswa.

Penelitian mengenai keefektifan layanan konseling kelompok dengan teknik self instruction dan teknik cognitive restructuring oleh (Hidayanti \& Ja'far, 2016) menyimpulkan bahwa kedua teknik tersebut efektif dalam mengurangi perilaku membolos siswa. Teknik instruksi diri dapat menggantikan keyakinan diri yang negatif pada diri konseli menjadi lebih positif. Sedangkan teknik cognitive restructuring membantu individu menata kembali pikiran-pikiran yang dianggap negatif dan tidak rasional terhadap dirinya selain itu teknik ini menemukan presepsipresepsi yang merugikan dirinya dan menggantikan ke prepsepsi yang lebih efektif untuk dirinya. Penelitian ini juga memandang bahwa teknik cognitive restructuring lebih efektif dari oada teknik self instruction hal ini karena seiao individu memahami keterkaitan antara perilaku yang dimilikinya dengan keyaknan dan presepsi yang dimiliki mengani dirinya.

Temuan penelitian lain dari (Saputra \& Prasetiawan , 2018) menunjukan terdapat kenaikan tingkat kepercayaan diri siswa antara sebelum dan sesudah diberi intervensi dengan konseling teknik cognitive defusion. Teknik ini menggunakan tahap rasional, pelatihan defusion, identifikasi pikiran negatif, defusion pikiran negatif, serta mengevaluasi dan menindak lanjut. Hal ini mengacu pada peningkatan kepercayaan diri bahwa kepercayaan diri dapat ditingkatkan melalaui teknik cognitive defusion.

Melalui pemaparan penelitian terdahulu, dapat disimpulkan bahwa kepercayaan diri siswa dapat ditingkatkan melalui beberapa teknik atau strategi. Salah satunya strategi restructuring cognitive menjadi salah satu strategi yang efektif dalam meningkatkan kepercayaan diri siswa selain itu terdapat teknik lain yang mempengaruhi kepercayaan diri. Tetapi berdasarkan hasil penelitian ini yang telah dipaparkan diatas penelitian ini secara signifikan tidak memiliki pengaruh dalam hal meningkatkan kepercayaan diri siswa. Adapun beberapa hal yang dapat dikaji kembali hal ini dapat disebabkan beberapa faktor diantaranya: (1) Pemberian perlakuan konseling kelompok relatif singkat hanya 6 kali pertemuan, seharusnya pemberian layanan konseling kelompok dilakukan relatif lebih lama bahkan 1 semester. (2) Pemberian layanan konseling kelompok kurang memadahi dan kurangnya 
kolaborasi antar layanan. Siswa memerlukan layanan yang integrasi dari beberapa layanan. (3) Pemberian konseling kelompok kurang memadahi dari segi pengalaman konselor dalam pengerucutan masalah konseli.

\section{SIMPULAN DAN SARAN}

Berdasarkan hasil penelitian dan pembahasan dari penelitian di SMP PGRI 1 Buduran Sidoarjo dapat disimpulkan bahwa penelitian ini tidak terdapat pengaruh yang signifikan penggunaan strategi restructuring cognitive dalam konseling kelompok terhadap kepercayaan diri siswa kelas VIII G di SMP PGRI 1 Buduran Sidoarjo meskipun hasil pre-test dan post-test mengalami peningkatan dan penurunan. Maka dapat diberikan saran sebagai berikut: (1) Bagi peneliti, perlu diadakan penelitian ulang terhadap kepercayaan diri siswa dengan cara menambah jam layanan konseling kelompok. (2) Bagi sekolah, perlu adanya kolaborasi antar layanan dalam Bimbingan dan Konseling. Selain itu jika mendapati siswa yang memiliki kepercayaan diri rendah alangkah lebih baik ditangani oleh guru BK sesuai bidangnya. (3) Bagi guru BK; a) Jika terdapat kepercayaan diri siswa yang rendah dapat dilakukan pelayanan konseling kelompok dengan strategi restructuring cognitive dengan cara menambah jam layanan konseling kelompok atau menggunakan layanan dengan waktu yang relative lama; b) Untuk memaksimalkan adanya perubahan dalam diri (konseli) siswa, tim guru BK hendaknya menambah layanan lain agar terjadi penguatan atau reinforcement sehingga tidak hanya mendapatkan layanan konseling kelompok tetapi layanan yang lainnya juga, seperti layanan konseling individu, bimbingan klasikal, bimbingan kelompok, dsb.

\section{DAFTAR RUJUKAN}

Agustine, P. (2018). Penerapan Strategi Restructuring Cognitive Untuk Meningkatkan Percaya Diri Siswa Kelas X IPS 1 SMAN Ponggok Kabupaten Blitar. Surabaya: Universitas Negeri Surabaya.

Creswell, J. W., \& Creswell, J. D. (2017). Research design: Qualitative, quantitative, and mixed methods approaches. Sage publications.

Drab, K. J. (2010). Aplication of cognitive Behavior Group Theraoy. Diambil kembali dari https://www.slideshare.net/kjdrab/applications-of-cbt-in-group-therapies

Fernandez, E., Salem, D., Swift, J. K., \& Ramtahal, N. (2015). Meta-analysis of dropout from cognitive behavioral therapy: Magnitude, timing, and moderators. Journal of Consulting and Clinical Psychology, 83(6), 1108.

Ghufron, M. N., \& Risnawati, R. (2010). Teori-Teori Psikologi. Jogjakarta: Ar-Ruzz Media.

Hidayanti, S. F., \& Ja'far, M. (2016). Keefektifan Self Instruction dan Cognitive Restructuring Untuk Mengurangi Perilaku Membolos Siswa SMK. Jurnal Bimbingan Konseling. Diambil kembali dari https://journal.unnes.ac.id/sju/index.php/jubk/article/view/18528/8919

Komara, I. B. (2011). Hubungan antara Kepercayaan Diri dengan Prestasi Belajar dan Perencanaan Karir Siswa. PSIKOPEDAGOGIA, 35-36.

Mudhar, \& Muwakhidah. (2017). Assesmen Psikologi Teknik Non Tes. Surabaya: Adi Buana University Press.

Nadiah, N. (2019). The Students' Self-Confidence in Public Speaking. ELITE JOURNAL, 1(1), 1-12.

Nurkia, S., \& Sulkifly. (2020). Penerapan Teknik Konseling Restrukturasi Kognitif Untuk Meningkatkan Kepercayaan Diri Siswa. Jamabura Guadiance and Counseling Journal. Diambil kembali dari https://ejournal-fipung.ac.id/ojs/index.php/jgcj/article/view/133/75

Oney, E., \& Oksuzoglu-Guven, G. (2015). Confidence: A critical review of the literature and an alternative perspective for general and specific self-confidence. Psychological reports, 116(1), 149-163.

Safta, C. G. (2015). Career decisions-A test of courage, responsibility and self-confidence in teenagers. ProcediaSocial and Behavioral Sciences, 203, 341-347.

Saputra, W. E., \& Prasetiawan , H. (2018). Meningkatkan Percaya Diri Siswa Melalui Teknik Cognitive Defusion. Jurnal Kajian Bimbingan dan Konseling. doi:file://C:/Users/BU\%20SITI/Downloads/2519-8507-1-PB.pdf

Saputra, W. N. (2017). Effectiveness of cognitive restructuring technique to reduce academic procrastination of vocational high school students. The International Journal of Counseling and Education, 18.

Saragih, M., Wibowo, M. E., \& Awalya. (2018). Cognitive Behavioral Therapy Group Counseling To Improve Body Image. Jurnal Bimbingan Konseling. Diambil kembali dari https://journal.unnes.ac.id/sju/index.php/jubk/article/view/25690

Sugiyono. (2017). Metode Penelitian Pendidikan Pendekatan Kuantitatif, Kualitatif, dan R\&D. Bandung: ALFABET.

Thimm, J. C., \& Antonsen, L. (2014). Effectiveness of cognitive behavioral group therapy for depression in routine practice. US National Library of Medicine National Institutes of Health. Diambil kembali dari https://www.ncbi.nlm.nih.gov/pmc/articles/PMC4209079/

Wenzel, A. (2017). Basic strategies of cognitive behavioral therapy. Psychiatric Clinics, 40(4), 597-609. 